\title{
The Blended Learning of Physical Education and Computer Class in
}

\section{Physical Colleges}

\author{
Qiang Chen ${ }^{1}$, Qinghan $\mathrm{Li}^{2}$ \\ ${ }^{12}$ Nanchang Institute of Science and Technology, P.E. Department; Nanchang Jiangxi 330108, \\ China \\ 346591653@163.com
}

KEYWORDS: Physical Colleges, Physical Education, Computer Class, Blended Learning

\begin{abstract}
With the continuous development of network information technology, more and more emphasis on sports teaching PE Colleges and computer integration of teaching, blended learning mode in this context will be born out. Blended learning is a fusion of traditional PE teaching new teaching model and network computer teaching, blended learning applications, improve the efficiency of teaching computer classes of Physical Education and Sports College, so that students can more efficiently complete the appropriate the task of teaching, so as to achieve the objectives and requirements of practice teaching.
\end{abstract}

\section{Introduction}

Concept of blended learning is first proposed by Professor He Kekang come, he thought, blended learning is mainly traditional teaching advantages and modern network information teaching strengths combine to give full play to the guidance and inspiration of teachers, effectively stimulate the enthusiasm of students and initiative, so as to achieve good teaching effect [1]. Traditional teaching advantages with the advantages of combining education information network, to achieve complementary advantages, mutual promotion purposes, thereby enabling sports and computer classes to achieve a high level of teaching. Teachers in the specific application of this teaching method, need to focus on the opportunity to choose the right time and teaching methods, so that students can form a complete knowledge of architecture.

\section{Advantages of Blended Learning}

\section{A. Blended Learning Highlighting the Role of Information Technology.}

The use of information technology to develop teaching resources. Generally, computer classes need to be applied to multimedia infrastructure, which the multimedia teaching resources requires a higher reality. Sports and computer classes blended learning, inseparable from the application of multimedia teaching resources, teaching resources usually these electronic journals, electronic books and multimedia courseware and other forms of existence [2]. Students carrying out the process of blended learning, you can take advantage of information technology to effectively integrate the appropriate teaching resources, so has the diversity of teaching resources, expanding, sharing and convenience features. Development and application of teaching resources, is an important advantage of blended learning.

The use of information technology to build a learning platform. Sports and computer class 
blended learning can be an effective use of information technology to build the corresponding learning platform. In general, online learning platform includes online learning, online tutoring, online student exchange, online testing and other forms of online job, it can provide real-time or non-real-time tutoring for students, so that students are free to choose suitable learning time [3]. Network Information Platform in blended learning, so that students can follow their own interests to choose the right study aids, but also to help students complete the teacher instructional design information through the network platform of teaching intelligent design tools, and thus make sport computer courses blended learning can highlight personalized to meet the needs of teachers and students bidirectional.

The use of information technology to track the learning process. In blended learning in information technology can also be used to keep track of students' learning process. Through information technology to record student learning activities, it can comprehensively assess student learning, and then based on the student's learning characteristics to adjust teaching strategies. IT recording and monitoring students' learning process, students will be able to archive the information processing to facilitate teachers to better supervise and guide students to complete the task of teaching [4]. For example, blended learning, teachers can establish correlation tracking database, among the students data entered into the database, and combined with the learning management system, which can be thought to develop and adjust their teaching strategies, formative assessment courses provided the corresponding reference data.

\section{B. Blended Learning Enables Information Technology Services the Education}

Blended learning emphasized by different learning styles and learning technologies integrated use, thus maximizing the effect of Physical Education and Computer Teaching and optimization. In blended learning, and not to abandon the traditional way of learning, but gradually make online learning and traditional classroom learning combine, and thus achieve good learning results. In the learning process, some traditional teaching methods and teaching methods also need to fit in [5]. Learning can not completely replace conventional classroom teaching, because there are some traditional classroom lessons worth learning and advantage. Learning needs and the actual situation of the students to adapt to meet the students' real needs, which can form the teaching system has practical value. Sports and computer class blended learning can not break away from traditional classroom teaching, learning needs and continuous improvement in the integration and development, and then build blended learning system so that information technology can better serve the education.

\section{The Application of Blended Learning}

\section{A. The Important Elements of Blended Learning.}

Teacher of Blended Learning. Teachers are blended learning important elements normally required to play a guiding role in blended learning. Network information technology to the blended learning process, gradually formed a hybrid of online learning for teachers and students to guide the combination of autonomous learning, thereby strengthening the interaction between teachers and students. Teachers teaching by designing sound and reasonable scenarios, we can continue to guide students to participate in blended learning, thereby enabling sports and computer classes to achieve good teaching.

Student of Blended Learning. Blended learning is the student body, students are important elements of blended learning. Blended learning the use of information technology to build e-learning platform, the ability to network with students learning the organic integration of 
classroom learning together, effectively improve the efficiency of student learning. Teachers can also use the e-learning platform to keep abreast of students' learning dynamic, based on the student's learning to adjust teaching strategies, so that teaching effectiveness can be maximized and optimized.

Resources of Blended Learning. Generally, based on blended learning based on the network information has a very rich learning resources, not only the traditional paper textbooks, as well as a variety of multimedia learning materials, database information. These learning materials after digital processing, it is possible in a multimedia computer or network environment, which could effectively stimulate student interest in learning, improve student learning initiative. At the same time, the digitized material can also design the process of teaching and teacher education program appropriate reference material.

\section{B. Specific Application Of Blended Learning.}

Prepare learning resources. Learning resources are mainly prepare teachers before class ready to electronic resources and teaching content related to online learning resources and print resources, different types of resources can play different roles in specific teaching. According to the characteristics of blended learning, learning resources can be divided into learning resources for the classroom learning and learning resources for independent study. Learning resources for the classroom teachers in the teaching process needs to be able to play a role of guidance and inspiration to help students understand and master the necessary knowledge, so that students can have the prior corresponding autonomous learning the basics. Learning resources for independent learning requires teachers to be able to deepen the learning content effectively to foster students' ability to learn.

Presenting learning resources. Sports and computer class blended learning, different learning resources have different presentation. Teachers need to characteristics of students, teaching objectives and teaching content to select the appropriate learning resources presentation, through the guidance of teachers and explain, making learning resources to achieve maximum effect. Teachers choose sports and computer classes in a variety of learning resources presentation, creation of scenarios can play, open up horizons of students, to stimulate students 'motivation to learn the role in order to cultivate the students' good thinking skills and practical ability.

Evaluation of student feedback. Evaluation and feedback is blended learning an important part of the teacher can easily keep abreast of students' actual learning. Teachers according to student learning to adjust teaching strategies, changes in teaching methods, in order to effectively improve the standard of teaching physical education and computer classes. Teacher evaluation and feedback process, to be applied to a variety of different means, to facilitate comprehensive understanding of the students learned some knowledge, but can also check whether the reasonable organization of teaching activities, teaching content is scientific and effective.

\section{Conclusion}

All in all, Colleges Physical Education and Sports computer class blended learning requires teachers to design reasonable and scientific applications, capable of specific teaching content and teaching objectives realistic combination, thereby allowing students to achieve higher learning in a good learning environment effect. 


\section{References}

[1] Study Du Jie-hyun, Shen and so on Moodle University Computer Basic Course blended learning design and practice [J] Computer Education, 2011,10: 61-65.

[2] Yang Zhifeng Sports Colleges Computer Courses Blended Learning application of [J] software GUIDE (educational technology), 2013,04: 21-23.

[3] soup climb all University Students blended learning model to explore [J] Chifeng University (Natural Science), 2015,06: 121-123.

[4] Jiangli Bing, renamed Agriculture, Xu Xuexia based B-Learning Physical Ability of educational technology research [J] Shandong Sports Science, 2013,01: 98-101.

[5] Wang Bin, Li Qin, Luo when mixed learning mode "Sports Psychology" teaching elements [J]. Hubei Sports Science, 2013,08: 718-720. 